\title{
Africanized and European honey bee worker ovarian follicle development response to racial brood pheromone extracts*
}

\author{
Tanya PANKIW ${ }^{\mathrm{a}}$, Celina GARZA ${ }^{\mathrm{b}}$ \\ ${ }^{a}$ Department of Entomology, Texas A\&M University, College Station, TX 77843-2475, USA \\ ${ }^{\mathrm{b}}$ Facultad de Ciencias Forestales, Universidad Autónoma de Nuevo León, Nuevo León, Mexico
}

Received 31 March 2006 - Revised 18 July 2006 - Accepted 9 August 2006

\begin{abstract}
Africanized and European worker honey bee (Apis mellifera L.) ovary follicle development response to Africanized and European larval extracts and synthetic brood pheromone were measured and modeled. Africanized workers had significantly greater baseline development than European workers. Racial extracts did not differentially affect Africanized or European follicle development. Africanized $\mathrm{EC}_{50}$ of brood pheromone for follicle development inhibition was 16 times greater than for European workers. The higher worker reproductive ability of Africanized workers appeared intrinsic and was not explained by the racial blend of pheromone or composition of the adult rearing environment. Higher colony-level reproduction apparently extends to the individual-level in Africanized bees.
\end{abstract}

Apis mellifera / brood pheromone / Africanized honey bee / ovary development

\section{INTRODUCTION}

In the honey bee (Apis mellifera L.) workers show facultative sterility, retaining the ability for ovarian follicle development and the production of haploid male eggs. Only about $1 \%$ of male eggs are derived from workers in colonies with a reproducing queen and diploid larvae (Ratnieks, 1993). In the absence of chemical inhibitor cues produced by the queen and/or larvae, worker follicle development may occur and the proportion of workers with developed follicles increases significantly (Arnold et al., 1994; Hoover et al., 2003; Mohammedi et al., 1998).

Honey bee hybrids of European (Apis mellifera L.) and African (Apis mellifera scutellata Lepeletier) races, commonly called Africanized bees, are known to have greater

Corresponding author: T. Pankiw, tpankiw@tamu.edu

* Manuscript editor: Klaus Hartfelder egg laying rate and ovarian follicle development than European worker counterparts (van der Blom and Velthuis, 1994; Hellmich II et al., 1986). Jay (1975) in contrast reported no significant difference in follicle development response of Apis mellifera adansonii Latreille and Apis mellifera ligustica Spinola workers reared for 10 days subject to various treatments such as; caged with a queen, with and without comb or, caged without a queen with and without comb, plus with and without pollen.

Little is known of race-based worker responses to putative racial blends of brood pheromone. Brood and extracts of larvae are known to partially inhibit worker ovarian follicle development among European bees (Jay, 1972; Jay and Jay, 1976; Jay and Nelson, 1973; Kropakova and Haslbachova, 1971; Kubisova, 1982; Kubisova and Haslbachova, 1978). There is a dose-dependent effect on ovarian follicle development in response to a 10-component synthetic blend of brood 
pheromone in European Apis mellifera of France. (Arnold et al., 1994; Mohammedi et al., 1998). Honey bee pheromones are multi-component blends of chemicals that may vary with genotype for individual components in the blend, quantity extracted from individuals, quantity of whole amount of pheromone, and/or the proportion of components to each other and the total blend (Pankiw, 2004). For example, Africanized workers synthesize an additional alarm inducing compound, 3-methyl 2-buten-1-yl acetate, not found in European workers (Hunt et al., 2003). Africanized and European queen mandibular pheromone component quantities and proportions vary significantly (Pankiw et al., 1996). However, there is no association between genotypic response and genotypic pheromone blend for alarm and queen mandibular modulated retinue and queen rearing inhibition (Hunt et al., 2003; Pankiw et al., 1995; Pettis et al., 1995). Here we tested the hypotheses that differential ovarian follicle development in Africanized and European workers is a consequence of (1) race of larval pheromone extract, (2) pheromone dose and, (3) genotypic composition of adults in the rearing environment. Additionally, Africanized and European ovarian follicle development in response to increasing amounts of brood pheromone was modeled, generating comparative estimates of the effective concentration and responses to brood pheromone for both races.

\section{MATERIALS AND METHODS}

\subsection{Worker ovarian follicle development responses to Africanized and European larval extracts}

Three European and three Africanized colony sources were used to obtain larvae and newly emerged adult bees. European queen sources (most similar to Apis mellifera ligustica) originated from northern California. Africanized queen sources originated from the Rio Grande Valley of Texas, which has been Africanized since at least 1990
Table I. Percent of brood pheromone components.

\begin{tabular}{lc}
\hline \multicolumn{1}{c}{ Compound } & \% worker blend ${ }^{1}$ \\
\hline ethyl linoleate & 1 \\
ethyl linolenate & 13 \\
ethyl oleate & 8 \\
ethyl palmitate & 3 \\
ethyl stearate & 7 \\
methyl linoleate & 2 \\
methyl linolenate & 21 \\
methyl oleate & 25 \\
methyl palmitate & 3 \\
methyl stearate & 17 \\
\hline
\end{tabular}

${ }^{1}$ Total esters $560 \mathrm{ng} /$ worker larva.

(Rubink et al., 1996; Sugden and Williams, 1990). European and African (Apis mellifera scutellata) maternal lineage was confirmed using mitochondrial DNA (mtDNA) analysis (Pinto et al., 2003). Africanized honey bee nuclear DNA is introgressed with an unknown amount of European nuclear DNA and mtDNA type represents an unbroken maternal lineage (Pinto et al., 2005).

Brood pheromone was prepared from $168 \mathrm{~g}$ of 4 th to 5 th instar larvae from each colony source. Using weight is a standard method to control for possible size and potential pheromone yield differences between groups when preparing pheromone extracts (Simon and Nicholelis, 2001). Larvae (168 g) were fully immersed in $100 \mathrm{~mL}$ of HPLC grade hexane (Sigma-Aldrich, St. Louis, MO) for $1 \mathrm{~min}$ at room temperature. This extract contained non-polar soluble compounds extractable from the surface of larvae such as the brood pheromone components listed in Table I, as well as cuticular hydrocarbons and unknowns. Prior to use, no more than 4 weeks later, extracts were stored at $-80{ }^{\circ} \mathrm{C}$ in amber glass vials with screw cap tops lined with Teflon.

Frames with mature pupae obtained from source colonies were placed in individual cages and maintained in a dark incubator $\left(+30{ }^{\circ} \mathrm{C}\right.$ and $\left.55 \% \mathrm{RH}\right)$ for $12 \mathrm{~h}$. Bees that emerged from these frames were paint marked a different color according to their $m t$ DNA type. A cage of plexiglass and wiremesh $\left(1635 \mathrm{~cm}^{3}\right)$ was stocked with three hundred newly emerged adult worker bees $<24 \mathrm{~h}$ old, 150 bees per $m t$ DNA type. For each colony pair, one cage was prepared for each treatment for a total of 9 cages. For each colony pair, cages were 


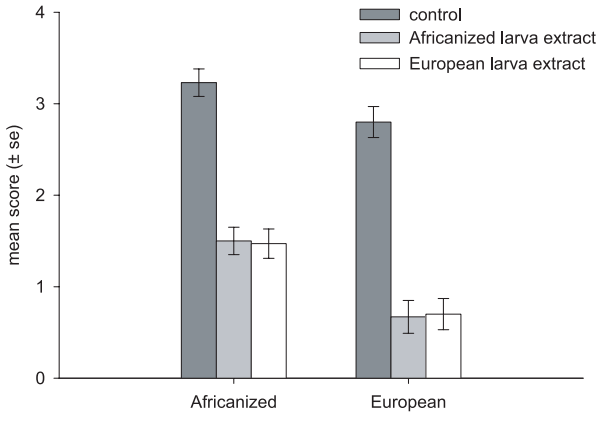

Figure 1. Africanized and European worker ovarian follicle development responses to hexane extracts of Africanized and European larvae.

randomly selected for subsequent daily treatments of (1) $7 \mathrm{~mL}$ of hexane as the no pheromone control, (2) $7 \mathrm{~mL}$ of Africanized larval extract, and (3) $7 \mathrm{~mL}$ of European larval extract. The treatments were applied to solvent rinsed clean glass plates $\left(40 \mathrm{~cm}^{2}\right)$. The hexane was completely evaporated prior to placing the plates into cages. A pollen paste diet of pure powdered pollen moistened with a $30 \%$ sucrose solution, as well as a vial of $30 \%$ sucrose solution (w/w) and, a separate vial of water were available ad lib and replaced daily. Bees were reared in cages for 14 days in an incubator maintained in the dark at $+34{ }^{\circ} \mathrm{C}\left( \pm 1{ }^{\circ} \mathrm{C}\right)$ and $50 \% \mathrm{RH}( \pm 5 \%)$. On the 15 th day bees were euthanized and stored at $-20{ }^{\circ} \mathrm{C}$ prior to dissection and follicle scoring. The follicles of 20 bees per mtDNA type from each cage were exposed under a dissection microscope. Follicle development was scored according to five classes: 0 , no follicle development; 1, slight enlargement; 2, presence of distinct cells leading to swellings and constrictions; 3 , presence of sausage-shaped cells; 4 , presence of fully formed eggs (Lin and Winston, 1998). Kruskal-Wallis and Mann-Whitney U models were used to analyze the score data (Sokal and Rohlf, 1995).

\subsection{Genotypic dose-dependent response to synthetic brood pheromone on worker ovarian follicle development}

The results of experiment 2.1 indicated that differential follicle development scores of Africanized and European workers were not a consequence of potential differences in larval extracts derived from
Africanized and European larvae (Fig. 1). Subsequently, synthetic brood pheromone was used in the following experiments allowing precise formulation of brood pheromone component quantities and proportions.

Six European and six Africanized colony sources, confirmed using mtDNA analysis (Pinto et al., 2005), were used to obtain newly emerged adult bees. Individual Africanized and European source colonies were paired, and pairs were coreared within the same cage; 150 bees per mtDNA type. For each colony pair, one cage was prepared for each treatment for a total of 30 cages. For each colony pair, cages were randomly selected for subsequent daily treatments of worker synthetic brood pheromone as ng/bee: 0, 5.6, 56, 560 and, 5600 (see Tab. I). Desired concentrations of brood pheromone were prepared from a single concentrated stock solution by serial dilution using $>99 \%$ isoporpanol (Sigma, St. Louis, MO). The treatments were applied to solvent rinsed clean glass plates $\left(40 \mathrm{~cm}^{2}\right)$. The isopropanol was evaporated prior to introducing the plates to cages. Food was provisioned as above and rearing conditions were the same. Pollen paste diet and consumption of liquids were measured daily and statistically analyzed using ANOVA (Sokal and Rohlf, 1995; SPSS, 2000). On the 15th day bees were euthanized and stored at $-20{ }^{\circ} \mathrm{C}$ prior to dissection and follicle scoring. The follicles of 30 bees per mtDNA type from each cage were exposed under a dissection microscope, and scored as above. The median follicle development score for each colony pair, mtDNA, and treatment was calculated. A dose-response curve was generated by mtDNA type with a four-parameter logistic function model based on the Marquardt-Levenberg algorithm (SigmaPlot 9.0, 2004; SPSS 11.5, 2000; Kleinbaum, 1996).

$$
Y=\min +\frac{\max -\min }{1+10^{\left(\log E C_{50}-X\right) \text { hillslope }}}
$$

where $Y$ was the average median maximum response, $X$ was the brood pheromone amount, $\max$ was the top of the curve, min was the bottom of the curve, $E C_{50}$ was the amount of pheromone that caused $50 \%$ follicle development inhibition (effective concentration threshold), and hillslope characterized the slope of the curve at its midpoint (Kleinbaum, 1996). The values of the parameters maximum response, $\mathrm{EC}_{50}$ and hillslope for each $m t$ DNA type were statistically compared using the $F$ test (SPSS, 2000). 


\subsection{Dose-dependent responses to brood pheromone on worker ovarian follicle development; mixed-mtDNA versus single-mtDNA cage environments}

To test for possible interacting effects of two mtDNA types within a single cage, we conducted the same experimental protocol detailed in 2.2 with the following exceptions. Three pairs of Africanized and European source colonies were selected and newly emerged adults reared in separate cages for each pheromone amount and control treatments. All other pheromone amounts and handling methods were the same as in 2.2. Median follicle scores were calculated for each cage and dose. A dose response curve was generated for each colony using the four-parameter logistic model based on the Marquardt-Levenberg algorithm, as above (SigmaPlot 9.0, 2004; SPSS 11.5, 2000; (Kleinbaum, 1996). $E C_{50}$ and hillslope values derived from mixed and single- $m t$ DNA cage rearing environments were compared using paired t-test analysis (Sokal and Rohlf, 1995; SPSS, 2000).

\section{RESULTS}

\subsection{Worker ovarian follicle development responses to Africanized and European larval extracts}

Kruskal-Wallis analysis supported the null hypothesis of no difference in follicle development score distributions among the three replicates in this experiment $\left(\chi^{2}=1.5,2 \mathrm{df}, P=\right.$ $0.5)$, therefore replicates were pooled in subsequent analyses. Overall, Africanized follicle development was significantly greater than European development (Mann-Whitney U = $11073.5, \mathrm{~N} 1=180, \mathrm{~N} 2=180, P<0.0001$; Fig. 1). Follicle score distributions were significantly different between the no pheromone control compared to the pheromone treated bees within each mtDNA type; Africanized: $\chi^{2}=6.7,2 \mathrm{df}, P<0.05$; European $\chi^{2}=5.3$, $2 \mathrm{df}, P<0.05$. There were no significant differences however among Africanized workers in the response to Africanized and European larval extracts $(\mathrm{U}=1952, \mathrm{~N} 1=60, \mathrm{~N} 2=60$, $P=0.42$; Fig. 1). Similarly, European follicle scores were not significantly different between Africanized and European larval extract treatments $(\mathrm{U}=1736, \mathrm{~N} 1=60, \mathrm{~N} 2=60, P=0.74$; Fig. 1).

\subsection{Modeling genotypic dose-dependent responses to synthetic brood pheromone on worker ovarian follicle development}

To compare baseline differences in follicle development between colonies within mtDNA type, we used follicle score data from bees reared in the no pheromone control. There were significant differences among African colonies (Kruskal-Wallis $\chi^{2}=35.8,5 \mathrm{df}, P<$ 0.0001 ) as well as among European colonies (Kruskal-Wallis $\chi^{2}=16.5,5 \mathrm{df}, P<0.01$ ). Overall, the African mtDNA type showed significantly greater follicle development than European mtDNA type (Tab. II; Fig. 2). Analysis of variance of $\mathrm{EC}_{50}$ results for effect of rearing pair $\left(\mathrm{F}_{5,5}=1.07, P>0.05\right), m t \mathrm{DNA}$ type $\left(\mathrm{F}_{1,5}=8.5, P<0.05\right)$ and, the interaction of pair $\times$ mtDNA (not calculated by SPSS) indicated only the mtDNA factor had a significant effect on $\mathrm{EC}_{50}$. The interaction of pair $\times$ mtDNA was not calculated by SPSS because all of the follicle development variation was attributable to the mtDNA factor in the ANOVA model. The mean effective concentration of brood pheromone capable of causing $50 \%$ inhibition of mean maximum follicle development was 16.2 times greater for African mtDNA than for European mtDNA bees. The mean slope value for African mtDNA bees was $0.44 \pm 0.10$ and for European mtDNA bees, $0.13 \pm 0.03\left(\mathrm{~F}_{1,5}=18.6, P<0.01\right)$. Pollen, $30 \%$ sucrose solution, and water consumption between replicates and treatments were not significantly different (ANOVA: replicates $\mathrm{F}_{2,10}=1.8, P=0.21$; treatment $\mathrm{F}_{3,10}=0.43$, $P=0.7)$. 
Table II. Brood pheromone dose-response effective concentration $\left(\mathrm{EC}_{50}\right)$ and hillslope values of ovarian follicle development scores of bees with European and African mtDNA types reared together in a cage ( 2 mtDNA) or reared in separate cages (1 mtDNA) for 14 days.

\begin{tabular}{cccccc}
\hline Pair & mtDNA & $\begin{array}{c}\mathbf{E C}_{\mathbf{5 0}} \\
2 \mathrm{mtDNA}\end{array}$ & $\begin{array}{c}\mathbf{E C}_{\mathbf{5 0}} \\
1 \mathrm{mtDNA}\end{array}$ & $\begin{array}{c}\text { Hillslope } \\
2 \mathrm{mtDNA}\end{array}$ & $\begin{array}{c}\text { Hillslope } \\
1 \mathrm{mtDNA}\end{array}$ \\
\hline \multirow{2}{*}{1} & African & 10.54 & 8.14 & 0.39 & 0.55 \\
& European & 1.78 & 0.43 & 0.09 & 0.09 \\
\multirow{2}{*}{2} & African & 27.31 & 43.49 & 0.33 & 0.34 \\
& European & 4.17 & 5.34 & 0.11 & 0.10 \\
\multirow{2}{*}{3} & African & 10.50 & 10.70 & 0.40 & 0.50 \\
& European & 1.51 & 0.21 & 0.09 & 0.20 \\
\multirow{2}{*}{4} & African & 65.84 & - & 0.33 & - \\
& European & 4.20 & - & 0.12 & - \\
5 & African & 66.50 & - & 0.33 & - \\
& European & 0.52 & - & 0.52 & - \\
6 & African & 17.12 & - & 1.00 & - \\
& European & 0.05 & - & 0.30 & - \\
\hline
\end{tabular}

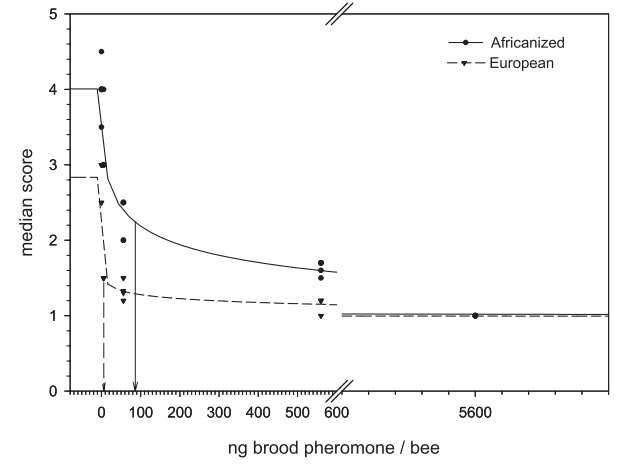

Figure 2. Four-parameter logistic regression model curves of Africanized and European worker dosedependent ovarian follicle development response to synthetic brood pheromone. The mean effective concentration $\left(\mathrm{EC}_{50}\right)$ of brood pheromone was 16 times greater for Africanized (solid arrow) versus European (hatched arrow) ovarian follicle development inhibition.

\subsection{Dose-dependent response to brood pheromone on worker ovarian follicle development; mixed-mtDNA versus single-mtDNA cage environments}

Paired t-test analyses were used to compare $\mathrm{EC}_{50}$ and hillslope values of African and European mtDNA colony sources that were reared together and apart (Sokal and Rohlf, 1995). The mean \pm se difference in $\mathrm{EC}_{50}$ values of those reared in mixed mtDNA versus single mtDNA cage environments was $-0.36 \pm 3.5$ and was not significantly different $(\mathrm{t}=-0.10$, $5 \mathrm{df}, P>0.05)$. Mean hillslope value differences, $1.2 \pm 1.2$, also were not significantly different $(\mathrm{t}=1.0,5 \mathrm{df}, P>0.05)$.

\section{DISCUSSION}

Invariably, Africanized workers showed significantly greater baseline ovarian follicle development than European workers in all experiments. Differential ovarian follicle development was not explained by potentially different hexane extracts of larvae from the different races. Preliminary gas chromatographic results characterizing brood pheromone of Africanized and European larvae suggest significantly different fatty acid ester profiles of same-aged larvae (Metz and Pankiw, unpubl. data). However, ovarian follicle response results here are consistent with a number of honey bee pheromone studies showing no correlation between race-based pheromone blend and racial response to pheromones. For example, Africanized and European worker sting pheromone blends are different, but alarm and defensive behavioral responses by Africanized 
and European workers is not dependant on the source of the pheromone (Hunt et al., 1999, 2003). A similar phenomenon has been observed with respect to queen mandibular gland pheromone. Africanized and European queen mandibular gland pheromone blends are different with respect to the proportions of the 2 major components (Pankiw et al., 2000), however retinue and queen rearing suppression responses by Africanized and European bees is not dependent on the this difference in blend composition (Pettis et al., 1995). Unlinked genetic influence on pheromone biosynthesis and responses makes biological sense. In this way semiochemical cues and responses may independently change by natural selection pressures without a potentially slower coordinated or costly change in the pheromone. This does not mean that change in pheromone does not necessarily affect pheromone response. For example, Africanized bees produce an alarm component, 3-methyl-2-buten-1-yl, not detectable from extracts of European workers (Hunt et al., 2003). This additional component of alarm pheromone more effectively recruits Africanized and European workers into alarm behavior but does not change the amount of inherent ability to recruit each race. Instead of acting to change recruitment response, the novel component is an efficient precursor of iso-pentyl acetate, the principal alarm component. Response is constrained by genotype, and blend may modulate genotypic responses such that genotypically high responders consistently show a greater response than genotypically lower responders, given the same pheromone stimulus. The phenomenon of genetically unlinked pheromone production and response suggests very dynamic and complex systems of chemical communication where the constituent parts are free to recombine, emerging as flexible and adaptive systems (Pankiw, 2004).

The effective concentration $\left(\mathrm{EC}_{50}\right)$ of brood pheromone was more than 16 times greater for the African compared to the European mtDNA type. Additionally, the mean slope value was significantly greater for African bees. These differences were more likely a consequence of a higher African maximum response than any other factor in the four-parameter model.
Rearing both mtDNA types of adults together or separately did not explain differences in baseline or pheromone modulated follicle development responses. Combined these results strongly suggest that at the individual worker level, the African mtDNA type is significantly more reproductive than the European mtDNA type. Brood pheromone effect on follicle development appeared to be a classical threshold response where mtDNA type constrained response, except at the highest dose where the responses of both mtDNA types converged. Incomplete inhibition of follicle development by brood pheromone is consistent with the observations of others (Arnold et al., 1994; Mohammedi et al., 1998) and is not necessarily a consequence of an incomplete synthesis of pheromone but equally likely points to multiple social cues necessary for complete inhibition and includes individuals that escape inhibition (Ratnieks, 1993). Our results conflicted with Jay's 1975 study that compares African and European worker ovarian follicle development but our study also differed in some key features. In this study, bees were 4 days older allowing more time for reproductive physiological change, sample sizes were larger, and up to 6 colonies per race versus 1 colony per race. The tropically evolved African honey bee, A.m. scutellata and African hybrids, are known for higher colony-level reproductive rate compared to temperate evolved European A. mellifera races (Winston et al., 1983). The higher colony-level reproductive rate of Africanized colonies appears to extend to the individual semi-sterile worker level and evidently an intrinsic trait.

\section{ACKNOWLEDGEMENTS}

This research was supported by grants from the USDA 58-6204-1-009, 2004-35302-15031, to T. Pankiw, as well as, the Texas Honey Bee Legislative Initiative. Appreciated assistance was provided by G.W. Burlin, D.R. Puente, R. Roman and, R. Sanchez. Handling of honey bees complied with current laws in the USA.

Réponse du développement des follicules ovariens des ouvrières d'abeilles domestiques africanisées et européennes à des extraits de phéromone de couvain des mêmes races. 
Apis mellifera / phéromone de couvain / développement ovarien / abeille africanisée / race

Zusammenfassung - Reaktion der Follikelentwicklung auf rassenspezifische Brutpheromone bei afrikanisierten und europäischen Bienenarbeiterinnen. Die als afrikanisierte Bienen bezeichneten Hybriden von europäischen (Apis mellifera L.) und afrikanischen (Apis mellifera scutellata) Bienenrassen sollen eine höhere Eilegerate und stärkere Follikelentwicklung haben als europäische Bienen. Wir prüften die Hypothese, dass die unterschiedliche Follikelentwicklung bei afrikanisierten und europäischen Arbeiterinnen eine Folge ist von (1) rassenspezifischen Komponenten des Larvenpheromons, (2) Dosierung des Pheromons und (3) der genetischen Zusammensetzung der zusammen gehaltenen Adultbienen. Auf der Basis der Pheromonkonzentrationen, die für eine Hemmung der Follikelentwicklung notwendig waren, wurde zusätzlich ein Modell für die Follikelentwicklung bei afrikanisierten und europäischen Arbeiterinnen entwickelt. Allgemeine Methoden: Die Rassezugehörigkeit (europäische vs. afrikanisierte Bienen) wurde über DNA ( $m t$ DNA)-Analysen bestätigt. Die Bienen wurden für 14 Tage im dunklen Brutschrank $\left(34{ }^{\circ} \mathrm{C} \pm 1{ }^{\circ} \mathrm{C}\right.$ und $50 \% \pm 5 \% \mathrm{RF}$ ) in Käfigen aus Plexiglas und Drahtgitter $\left(1635 \mathrm{~cm}^{3}\right)$ gehalten. Am 15 . Tag wurden die Bienen getötet und bei $-20{ }^{\circ} \mathrm{C}$ eingefroren. Die Ovariolen von 20-30 Bienen pro $m t$ DNA-Typ und Käfig wurden unter einem Präpariermikroskop untersucht. Die Follikelentwicklung wurde in 5 Klassen von $0=$ keine Entwicklung bis $4=$ voll entwickelte Eier eingeteilt. Es wurden drei Experimente durchgeführt. In Experiment 1 wurde die Reaktion der Follikelentwicklung auf Extrakte von europäischen bzw. afrikanisierten Larven gemessen. Bei den afrikanisierten Bienen waren die Follikel signifikant weiter entwickelt als bei europäischen Bienen (Abb. 1). Weder bei den afrikanisierten noch bei den europäischen Bienen gab es Unterschiede zwischen den Experimenten mit afrikanisierten bzw. europäischen Larvenextrakten. In Experiment 2 wurde die dosisabhängige Follikelentwicklung bei afrikanisierten und europäischen Arbeiterinnen nach Applikation eines synthetischen Brutpheromons (Tab. I) gemessen. Die $\mathrm{EC}_{50}$ gibt die durchschnittliche effektive Konzentration des Larvenpheromons an, bei der die maximale Follikelentwicklung um $50 \%$ reduziert wird. Diese $\mathrm{EC}_{50}$ war bei afrikanisierten Bienen 16,2 mal höher als bei europäischen Bienen (Abb. 2). In Experiment 3 testeten wir mögliche Interaktionen zwischen afrikanisierten und europäischen Bienen im selben Käfig auf die Follikelentwicklung. Die durchschnittlichen Unterschiede in der $\mathrm{EC}_{50}$ zwischen Käfigen mit gemischten Arbeiterinnen und Arbeiterinnen einer
Bienenrasse betrugen $-3,6 \pm 3,5$ und waren nicht signifikant $(t=-0,10,5 \mathrm{df}, P<0,05)$. Zusammenfassend bleibt festzuhalten, dass afrikanisierte Arbeiterinnen bei der Follikelentwicklung eine signifikant höhere Reaktionsschwelle gegenüber Brutpheromonen haben als europäische Bienen, unabhängig von der Herkunft des Pheromons und den Haltungsbedingungen der Bienen.

\section{Honigbienen / Apis mellifera / Brutpheromone / afrikanisierte Bienen / Ovarentwicklung}

\section{REFERENCES}

Arnold G., Le Conte Y., Trouiller J., Hervet H., Chappe B., Masson C. (1994) Inhibition of worker honeybee ovary development by a mixture of fatty acid esters from larvae, C.R. Acad. Sci. Paris, Sci. Vie 317, 511-515.

Blom van der J., Velthuis H.H.W. (1994) Simultaneous queen raising and egg laying by workers in Africanized honeybee colonies (Apis mellifera L.) in Costa Rica, Apidologie 25, 367-374.

Hellmich II R.L., Danka R.G., Collins M.A., Rinderer T.E. (1986) Laying-worker production of drones in mixed colonies of Africanized and European honey bees (Hymenoptera: Apidae), Ann. Entomol. Soc. Am. 79, 833-836.

Hoover S.E.R., Keeling C.I., Winston M.L., Slessor K.N. (2003) The effect of queen pheromones on worker honey bee ovary development, Naturwissenschaften 90, 477-480.

Hunt G.E., Collins A.M., Rivera R., Page R.E., Guzman-Novoa E. (1999) Quantitative trait loci influencing honeybee alarm pheromone levels, J. Hered. 90, 585-589.

Hunt G.J., Wood K.V., Guzman-Novoa E., Lee H.D., Rothwell A.P., Bonham C.C. (2003) Discovery of 3-methyl-2-buten-1-yl acetate, a new alarm component in the sting apparatus of Africanized honeybees, J. Chem. Ecol. 29, 453-463.

Jay S.C. (1972) Ovary development of worker honeybees when separated from worker brood by various methods, Can. J. Zool. 50, 661-664.

Jay S.C. (1975) Factors influencing ovary development of worker honeybees of European and African origin, Can. J. Zool. 53, 1387-1390.

Jay S.C., Nelson E.V. (1973) The effects of laying worker honeybees (Apis mellifera L.) and their brood on the ovary development of other worker honeybees, Can. J. Zool. 51, 629-632.

Jay S.C., Jay D.H. (1976) The effect of various types of brood comb on the ovary development of worker honeybees, Can. J. Zool. 54, 1724-1726. 
Kleinbaum D.G. (1996) Logistic Regression: A SelfLearning Text, Statistics in Health Sciences, Springer, New York.

Kropakova S., Haslbachova H. (1971) The development of ovaries in worker honey bees in queenright colonies examined before and after swarming, J. Apic. Res. 10, 57-61.

Kubisova S. (1982) Effects of fractions of larval extracts on the development of ovaries in caged worker honey bees, Acta Entomol. Bohemoslov. 79, 334-340.

Kubisova S., Haslbachova H. (1978) Effects of larval extracts on the development of ovaries in caged worker honey bees, Acta Entomol. Bohemoslov. 75, 9-14.

Lin H., Winston M.L. (1998) The role of nutrition and temperature in the ovarian development of the worker honey bee (Apis mellifera), Can. Entomol. $130,883-891$.

Mohammedi A.P., Crauser D., Le Conte Y. (1998) Effect of aliphatic esters on ovary development of queenless bees (Apis mellifera L.), Naturwissenschaften 85, 455-458.

Pankiw T. (2004) Cued in: honey bee pheromones as information flow and colony decision-making, Apidologie 35, 217-226.

Pankiw T., Winston M.L., Slessor K.N. (1995) Queen attendance behavior of worker honey bees (Apis mellifera L.) that are high and low responders to queen mandibular pheromone, Insect. Soc. 42 , $371-378$

Pankiw T., Winston M.L., Plettner E., Slessor K.N. (1996) Mandibular gland pheromone components of European and Africanized honey bee queens (Apis mellifera L.), J. Chem. Ecol. 22, 605-615.

Pankiw T., Winston M.L., Fondrk M.K., Slessor K.N. (2000) Selection on worker honey bee responses to queen pheromone (Apis mellifera L.), Naturwissenschaften 87, 487-490.

Pettis J.S., Winston M.L., Collins A.M. (1995) Suppression of queen rearing in European and Africanized honey bees Apis mellifera L. by synthetic queen mandibular gland pheromone, Insect. Soc. 42, 113-121.

Pinto M.A., Johnston J.S., Rubink W.L., Coulson R.N., Patton J.C., Sheppard W.S. (2003) Identification of Africanized honey bee (Hymenoptera: Apidae) mitochondrial DNA: Validation of a rapid polymerase chain reaction-based assay, Ann. Entomol. Soc. Am. 96, 679-684.

Pinto M.A., Rubink W.L., Patton J.C., Coulson R.N., Johnston J.S. (2005) Africanization in the United States: Replacement of feral European honeybees (Apis mellifera L.) by an African hybrid swarm, Genetics 170, 1653-1665.

Ratnieks F.L.W. (1993) Egg-laying, egg-removal, and ovary development by workers in queenright honey bee colonies, Behav. Ecol. Sociobiol. 32, 191-198.

Rubink W.L., Luévano-Martínez P., Sugden E.A., Wilson W.T., Collins A.M. (1996) Subtropical Apis mellifera (Hymenoptera: Apidae) swarming in dynamics and Africanization in northeastern Mexico and southern Texas, Ann. Entomol. Soc. Am. 89, 243-251.

SigmaPlot 9.0 (2004) SPSS Science software, Chicago Ill.

Simon S.A., Nicholelis M.A.L., Ed. (2001) Methods in Chemosensory Research. NY: CRC Press, New York.

Sokal R.R., Rohlf F.J. (1995) Biometry, The principles and practice of statistics in biological Research, W.H. Freeman and Company, New York.

SPSS 11.5 (2000) SPSS Science software, Chicago, Ill

Sugden E.A., Williams K.R. (1990) October 15: the day the bee arrived, Gleanings Bee Culture 119 , 18-21.

Winston M.L., Taylor O., Otis G.W. (1983) Some differences between temperate European and tropical African and South American honeybees, Bee World 64, 12-21. 